\title{
Timothy Brook
}

\author{
NINE SLOUGHS: PROFILING THE CLIMATE \\ HISTORY OF THE YUAN AND MING DYNASTIES, \\ $1260-1644 * \dagger$
}

I have written this essay to address what I regard as a pressing need among China historians for a stronger model of climate change and its impact on state and society during the imperial period. We have all become acutely conscious of climate change as an element of our own world, yet few of us have considered the impact of climate, particularly climate change, on our subjects of study. China is not without its climate historians, and yet the collective research is still in an early phase. ${ }^{1}$ Aware of this problem for some time, I published preliminary findings in the form of a chronological profile of climate anomalies through the Yuan and Ming dynasties in $2010 .^{2}$ Burying my findings in a textbook has meant that the periodization offered there has captured the interest of some students but gone largely ignored by scholars in the field. Since then I have done further research and have revised some of those findings, and would now like to offer a fuller presentation of methods and findings.

I am not a climate historian, but a social historian who has been dragged to climate history by the growing realization that climate sets fundamental parameters within which people organize their social existence. Most social historians are already aware of the impact of climate on the patterns and conflicts through which people negotiated their social existence, so there is nothing new in my pointing out the environmental context of social action. What I feel is needed beyond this is a framework within which to identify and situate moments of environmental stress, to see climate as an active rather than fixed factor. The practice of our intellecutal forebears, from Karl Wittfogel to Owen Lattimore, was to generalize a static portrait of the environmental conditioning of social life. In Wittfogel's case, it was to argue that the inadequacy of rainfall,

\footnotetext{
University of British Columbia, e-mail: tim.brook@ubc.ca

*I thank Richard Unger, Nicola di Cosmo, Peter Perdue, and Jonathan Schlesinger for their helpful advice in the course of writing this essay.

${ }^{\dagger}$ This article has been corrected since original publication. An erratum notice detailing this change was also published (doi:10.1017/jch.2017.12).

${ }^{1}$ In English, see, among others cited in this essay, Robert Marks, Tigers, Rice, Silk, and Silt: Environment and Economy in Late Imperial South China (Cambridge: Cambridge University Press, 1998); Jiayan Zhang, Coping with Calamity: Environmental Change and Peasant Response in Central China, 1736-1949 (Vancouver: University of British Coumbia Press, 2014).

${ }^{2}$ Timothy Brook, The Troubled Empire: China in the Yuan and Ming Dynasties (Cambridge, Mass.: Harvard University Press, 2010), 71-78, 270.
} 
particularly in north China, led to the construction of large-scale riverine irrigation systems, which in turn necessitated state investment and supervision; from this flowed his model of hydraulic despotism. ${ }^{3}$ For Lattimore, the main environmental feature of his analysis was the distinction between the ecologies of the zone north of the Great Wall, which roughly coincides with the 25 centimeter isohyet (the line marking precipitation below and above that level), and conditions south of the Great Wall, resulting in the cultural mix of steppe and sown. ${ }^{4}$ Their work, however controversial, pointed to a basic understanding of history that the ill-tempered call environmental determinism and the rest of us understand as a sensible awareness of the impact of the physical limits on how people live. These earlier static portraits were created before our current awareness of climate change, and are insufficient as paradigms for understanding the often intricate relationship between climate anomalies and the stress that they impose on society and the state. It is to climate change, then, that this essay invites readers to turn their attention: to swings in temperature and precipitation over the Yuan and Ming dynasties from the mid-thirteenth century to the mid-seventeenth.

Let me begin with an example of the sort of documentary material that led this lateMing social historian to the problem of climate. The passage that follows is taken from a memoir written in the 1670s by Zeng Yuwang 曾羽王, a county-school graduate (shengyuan 生員) living next to a military base in the countryside outside Shanghai. The 1640s was the most tumultuous decade of this man's life and his family's fortunes. Though Zeng was allowed to re-register as a government student in the local school in 1651 , he won no degree beyond the first. The trauma he suffered is the story to which he constantly returns in his memoir. Here is a taste of what he recorded of the years leading up the fall of the Ming:

In 1641, a great drought seized our land, and locusts filled the skies. By the back wall of our compound they were piled to a depth of over a foot. They stripped the six $m u$ 畧 [approx. $0.4 \mathrm{ha}$ ] of paddy fields Tenant Ye had planted, leaving not one weed. I saw him [staring at his field] in tears, powerless to do anything.... Walking home, I had to cover my face with a fan. I could barely stand up under the weight of the locusts clinging to my fan and to my clothes and hat....

Next year [1642] was the great famine. People died in countless numbers.... Our family found ourselves short of rice, so my father ordered our household bodyguard Wang Chang to hump the rice one bag at a time up from our shipping barge. After Wang was attacked by someone on the road, it was not possible to carry even a dou 斗 [10.5 liters] of rice in public. The price of rice rose by the day, and all the markets near and far shut down. Our family had no choice but to send Wang out to buy grain. He tramped north and south looking for rice but was able to scrape together only five sheng 升 [five liters]. Fortunately we had several shi [hectoliters] of barley on hand and were able to survive.

\footnotetext{
${ }^{3}$ Karl Wittfogel, Oriental Despotism: A Comparative Study of Total Power (New Haven: Yale University Press, 1957).

${ }^{4}$ Lattimore was critical of a geographical determinism that imputed changelessness to the "primitive" societies of Asia; see his "The Geographical Factor Mongol History," and "An Inner Asia Approach to the Historical Geography of China," in his Studies in Frontier History: Collected Papers 1929-1959 (London: Oxford University Press, 1962), 251-58, 492-500. Lattimore's influence was formative for Joseph Fletcher; see "The Mongols: Ecological and Social Perspectives," Harvard Journal of Asiatic Studies 46:1 (June 1986), 11-50.
} 
In the first month of that year [1642] I went with Fang Ai and Zhou Yinke to take the exams in Jiangyin. All along our route home in the fourth month, we saw corpses scattered about in the fields, and innumerable children abandoned by the side of the road.... To be walking properly attired down an unending road of corpses was a nightmare the likes of which I had never known. Approaching the village, we saw six or seven people stripping bark off elm trees....

When the dynasty fell, people were cut down like grass. On my way home from Zhoupu [in the fourth month of 1645] I stopped at Xinchang to get news from Fang, but when I reached Lower Sandbank I noticed that everyone was armed, so I turned round and went back. Only when order returned in the ninth month was it safe to travel on the roads. This was even worse than the famine. ${ }^{5}$

Much in these few sentences catches the eye of the social historian: the loss of the harvest of 1641, the polarization of rich and poor, price fluctuation, the capacity of the rich to buy into distant grain markets and their reliance on the poor to manage their economic strategies, the shutting down of markets, the effect of social disorder on famineresponse measures, the continuation of the examination system in spite of the social chaos, the importance of gentry intra-class relations, and finally the breakdown of social order and the resort of violence. But there is material of equally great interest for the climate historian: the onset of drought and its effects on both human and insect populations, with failed harvests, famine mortality, price rises, and social disorder as the effects of climate change. I may be better equipped to discover the social experience of climate change than to reconstruct climate change itself, but the vivid co-presence of environmental factors and social suffering in this text—which the author himself linkshas emboldened me to seek data in this and other texts of the late-imperial period with an eye to making a contribution to the history of China's climate. A more cautious historian may not entirely endorse this approach, but this is my bid to demonstrate its value.

\section{CLIMATE HISTORY}

Climate shapes human history most immediately in terms of its impact on the fundamental tasks of every society to produce enough food to feed the population and enough clothing and shelter to keep them warm, and thereby withstand the scourges of famine, disease, and war. When climate fluctuates, it alters the ability of populations to perform these tasks, often disastrously so. At issue is the amount of energy that the earth receives from the sun. That energy is differentially distributed by region, fluctuates within the seasonal cycle, and may as well ebb and flow in the longer term (in what are called Malinkovitch cycles). Before industrialization, two factors could alter the shortterm energy relationship between sun and earth. One is depressed solar radiation due to sunspots or the ejection of solar matter. The other is volcanic eruption, which spews aerosols into the atmosphere that block solar energy and reflect it back into space. In both cases, the result is less solar energy reaching the earth's surface. This reduction in energy leads directly to a fall in temperatures and, depending on how long solar

\footnotetext{
${ }^{5}$ Zeng Yuwang 曾羽王, “Yiyou biji” 乙酉筆記, reprinted in Qingdai riji huichao 清代日記會抄, edited by Shanghai shi wenwu baoguan weiyuanhui 上海市文物保管委員會 (Shanghai: Shanghai renmin chubanshe, 1982), 7-8, 12, 18.
} 
radiation is disrupted, indirectly to a variety of other climate anomalies, including alterations in precipitation and changes in the patterns of wind and water circulation across the earth's surface. The impact of these variations on human welfare can range from dearth and depression to starvation, epidemics, and rebellion.

Before instrumental records of climate fluctuation began to be kept worldwide in the 1860s, climate historians of earlier periods have to rely on proxy data such as tree rings (from which dendrochronologists reconstruct the precipitation and temperature conditions that influence cell growth) and glacial ice core samples (in which water molecules are analyzed for their isotopic weight or the presence of volcanic sulphur) to detect variations that point to changes in climate. This research has contributed to a widely shared gross periodization covering the past millennium. This periodization starts with the Mediaeval Maximum or Mediaeval Warm Period (approximately 10001300), followed by a colder period, usually referred to as the Little Ice Age. Some prefer to delay the onset of the Little Ice Age to roughly 1580, treating the preceding centuries as a transitional period leading up to the Little Ice Age, though the more common view regards the fourteenth century as part of a long period extending, with long bouts of warmer weather, down to the mid-nineteenth century. ${ }^{6}$ The coldest phase of the Little Ice Age (approximately 1645-1715) has been tagged the Maunder Minimum, named after astronomers Annie and Walter Maunder, who noted a decrease in sunspot activity during this period and linked this phenomenom to colder weather.

This chronology is not sufficiently fine to allow us to deduce the climate of any particular area from the general model; regional variation is always too great. Nonetheless, given that the earth, in terms of energy input, is a single system, climate forcingchanges in climate induced by alterations in the earth's access to solar energy - can be expected to have an impact, however unevenly distributed throughout the system, which is to say that our models of climate need to be generated from many different locations and many different sources. Given its size and the density of documentary record, China clearly has a role to play in this work.

Chinese climate scientists have already contributed much to this research since the 1990s. They have made use of a wide range of proxies, including some of the documentary sources used in this study, to model climate change over the past half-millennium, and in a few cases, over the past two millennia. Fourteen of these reconstructions of long-term shifts in temperature were usefully reviewed ten years ago by Ge Quansheng 葛全勝 and his colleagues. ${ }^{7}$ Ge's team explained the variations in their findings on the basis of the regions from which they drew their data, but they found that when the data were resolved to thirty years rather than ten (all the studies employed the decade as the unit of analysis), the differences among these studies' findings effectively disappeared. In all cases, the outlines of the Mediaeval Warm Period and the Little Ice Age are eminently

\footnotetext{
${ }^{6}$ Emmanuel Le Roy Ladurie, Histoire humaine et comparée du climat, I: Canicules et glaciers (XIIIeXVIIIe siècle) (Paris: Fayard, 2004), 17-29. For a summary of the state of the field on the Little Ice Age based on standard proxies, see Michael Mann et al., "Global Signatures and Dynamical Origins of the Little Ice Age and Medieval Climate Anomaly," Science 326 (Nov. 2009), 1256-60.

${ }^{7}$ Ge Quansheng, Jingyun Zheng, Yanyu Tian, Wenxiang Wu, Xiuqi Fang, and Wei-Chyung Wang, "Coherence of Climatic Reconstruction from Historical Documents in China by Different Studies," International Journal of Climatology 28:8 (2008), 1007-24.
} 
visible in their findings, thus largely confirming what has become the standard chronology.

The purpose of the present study is to work exclusively and more intensively from documentary evidence in order to develop a finer chronology for climate change in China, calibrated not to atmospheric shifts but to human experience. That Ge Quansheng and his team noted a high correlation between findings based on natural indicators and those based on documentary evidence is encouraging for the approach taken in the present study. The period covered extends from Khubilai's elevation as Great Khan of the Mongols in 1260, eleven years prior to his declaration of the founding of the Yuan dynasty in 1271, to the Manchu invasion in 1644 and the collapse of the Ming dynasty.

These boundaries reflect the long-established pattern of periodizing Chinese history by dynasty. However arbitrary the clocking of time by dynasty may seem, it does have the virtue of being the calendar by which Chinese organized their documentary record. These otherwise arbitrary boundaries are made particularly persuasive by the timing of the formation of the Mongol and Manchu states in China in relation to the two major shifts in climate between the thirteenth and the eighteenth centuries, the end of the Mediaeval Maximum in the late thirteenth century and the onset of the Maunder Minimum in the mid-seventeenth. One of the hypotheses arising from the research done for this essay is that neither simultaneity is coincidental: that both moments of regime change, carried out by the movement of massive military forces heavily reliant on horse fodder, were influenced by falling temperatures in the home territories of the Mongols in the mid-thirteenth century, and of the Manchus in the mid-seventeenth. ${ }^{8}$

\section{THE DATA}

The analysis presented in this essay rests on reports of climate anomalies and their effects drawn from the documentary record of the Yuan and Ming dynasties. Documentary proxies have their limits, and it is important to acknowledge these before proceeding.

Documentary references to weather do not come with the sorts of metrics that are built into instrumental records. When someone on the ground comments that the weather was colder or warmer than normal, or notes that the year was receiving more or less rain than usual, he is appealing not to an absolute metric than can confidently be measured, but rather to what might be called the adjusted metric of common perception. What is "normal" or "usual" is constantly under adjustment as the people who experience climate themselves adjust to their physical environment. They do this by changing their clothing, altering their crops, or building or abandoning infrastructure designed to respond to different conditions. Normality moves with these adjustments. Even a

\footnotetext{
${ }^{8}$ Another decisive moment in the history of Inner Asia, before the period under study here, is the expansion of the Mongol Empire early in the thirteenth century. Nicola di Cosmo and his collaborators have argued that this expansion was driven not by climate deterioration but by greater rainfull, which improved pasturage for horses; see Neil Pederson, Amy Hessl, Nachin Baatarbileg, Kevin Anchukaitis, and Nicola Di Cosmo, "Pluvials, Droughts, the Mongol Empire, and Modern Mongolia," Proceedings of the National Academy of Sciences 111 (2014), 4375-79; also Nicola di Cosmo, "Why Qara Qorum? Climate and Geography in the Early Mongol Empire," in Archivum Eurasiae Medii Aevi 21 (2014-15), edited by P.B. Golden et al. (Wiesbaden: Harrassowitz, 2015), 74, 76.
} 
rise or fall in temperature of a single degree Celsius, which is quite rare and may feel modest in any particular circumstance (rather than in the aggregate), can be well within the latitude within which people adjust their sense of normalcy. Normality may not map onto a universally shared external standard, but to the extent that it will be socially shared, it is not a purely subjective measurement.

A strength of documentary proxies, notably in China's case, is the volume of material from which data can be drawn. It becomes increasingly abundant as we move closer to the end of the imperial era, but it exists in some density well into the past. This means not only that there is much information related to climate to collect, but that we can expect the data to display both continuity and a good measure of internal consistency. A single written reference to a drought may come with no quantitative weight, unless it is the number of people affected, but the continuity of drought reporting guides which droughts the documentary record includes and which it does not, generating a certain consistency of reporting over time. These strengths of the Chinese record alleviate some of the usual concerns with the documentary record elsewhere. ${ }^{9}$

This study relies on two documentary genres, both of them produced by the state. ${ }^{10}$ The first is the official dynastic history, in this case the histories of the Yuan and Ming, Yuan shi 元史 and Ming shi 明史. The dynastic histories have been mainstays of research on historical disasters since the 1930s, when disaster history became a popular topic among historians of China. ${ }^{11}$ Produced after the collapse of the dynasty it chronicled, the dynastic history was the official record of what happened, and thus of why the legitimacy that the previous dynasty once commanded had passed to its

\footnotetext{
${ }^{9}$ On the values and limits of the documentary approach to climate history, see Pierre Alexandre, Le Climat en Europe au Moyen Age: à l'histoire des variations climatiques de 1000 à 1425, d'après les sources narratives de l'Europe occidentale (Paris: École des hautes études en sciences sociales, 1987), 9-42. Alexandre draws from a remarkable ensemble of 2,390 texts selected as reliable from a candidate corpus of over 3,500 texts, plus another 440 notices extracted from such documents as account books. For a persuasive study linking this sort of evidence to political effects in Europe, see Michael McCormick, Paul Edward Dutton, and Paul A. Mayewski, "Volcanoes and the Climate Forcing of Carolingian Europe, A.D. 750-970," Speculum 82 (2007), 865-95.

${ }^{10}$ Another official production that could have been used for the Ming dynasty is the court diary of each reign, the Ming shilu 明實錄 (Veritable Records of the Ming). This source includes climate reports from field administrators, though these were submitted reactively and do not readily generate a consistent archive. As Huang Yunmei 黃雲眉has observed of the disasters listed in Ming shi 明史 (the official dynastic history), some appear in the Veritable Records but some do not; Mingshi kaozheng 明史考證 (Beijing: Zhonghua shuju, 1979), 1.264. References to natural disasters have been conveniently extracted in the Ziran zaiyi 自然災異 volume of the Ming shilu leizuan 明實錄類纂 series (Wuhan: Wuhan chubanshe, 1993). In addition to state documents, one could also mine private publications, such as Zeng Yuwang's memoirs, for climate data. Their dispersed character and inconsistency of reporting, however, make it difficult to put them to statistical use.

${ }^{11}$ The first comprehensive study using the dynastic histories is Chen Gaoyong 陳高傭, Zhongguo lidai tianzai renhuo biao 中國歷代天災人禍表 (Shanghai: Jinan daxue, 1939; repr., Shanghai shudian, 1986); the compilers supplemented these with material culled from the Qing compendium, Tushu jicheng 圖書集成. Satō Taketoshi 佐藤武敏, Chūgoku saigaishi nenpyō 中国災害史年表 (Tokyo: Kokusho kankōkai, 1993), adds data from the imperial biographies in the dynastic histories. Song Zhenghai 宋正海, Zhongguo gudai ziran zaiyi xiangguanxing nianbiao zonghui 中國古代自然災異相關性年表總匯 (Hefei: Anhui jiaoyu chubanshe, 2002), also uses the dynastic histories, supplemented with data from the Veritable Records and local gazetteers. Although this essay relies on much the same sources, the approach here seeks to address climate history, not disaster history.
} 
successor. The genre cleaves to a certain narrative of rise and fall: a dynasty begins with a dynamic founder supported by a cadre of devoted followers, and it ends in a fog of disorder abetted by incompetent officials and pitted by hunger and war. The Yuan and Ming can plausibly be made to fit this dynastic narrative. Each can claim a vigorous founder, Khubilai Khan and Zhu Yuanzhang, and each collapsed in what looks like a perfect storm of imperial neglect, bureaucratic infighting, and popular rebellion. Even climate has a role in this narrative; as the Yuan shi declares, "Humans in their relationships to Heaven and Earth make a three-cornered world: each has its place in the arising of disaster and good fortune." 12 When all is well, Heaven ensures that the climate is benign; when all is in chaos, Heaven will unleash storms and celestial perturbations to strike terror into the hearts of whomever it chooses to terrify. This is why climate anomalies are considered record-worthy.

The description of a three-cornered world is taken from the sentence that opens the disasters section of the Yuan shi. The section is entitled wuxing 五行, the Five Elements or Five Phases through which matter and energy were understood to cycle. This is where court historians filed data on Heavenly, Earthly, and Human anomalies. Heaven causes temperatures to fluctuate, rain to fall, hurricanes to blow, lightning to strike, and dragons to wreak havoc. Earth produces seismic quakes, unleashes floods, and spawns plagues of insects. Humans do the rest by murdering parents, assasinating rulers, and waging wars. All are signs of a disturbed cosmic order. Those of sufficient scale deserved to be entered into the official record. Climate anomalies were evidence to which dynastic historians could turn to evaluate a dynasty's fitness to continue. These were proxies not for climate but for the health of the realm, but they succeed in reporting on both. ${ }^{13}$

A citation in the Five Phases section of a dynastic history is usually telegraphic: data, location, and incident occupy no more than one line of text. These citations are grouped by type and listed in sequence by year. The categories and their arrangement variy slightly from history to history. The Yuan shi includes reports of floods, hail, thunder, fire, unseasonable frosts and snows, lack of snow when it should have fallen, ice storms, excessive rainfall, droughts, locusts, famines, epidemics, high winds, insect infestations, landslides, earthquakes, and dragon manifestations. ${ }^{14}$ The Ming shi uses roughly the same categories, though in a different sequence and framed by a milder cosmological argument. ${ }^{15}$ These

\footnotetext{
${ }^{12}$ Song Lian 宋濂, ed., Yuan shi 元史 (Bejing: Zhonghua shuju, 1976), juan 50.

${ }^{13}$ Theoretically the proxy quality of disaster data could have encouraged compilers to pile on references to natural disasters during the reigns of unfit emperors, and discouraged them from recording too many disasters during approved reigns. However, my reading of the dynastic histories has not given me reason to suspect a heavy editorial hand of this sort at work. Court historians were charged with producing history-worthy records, and took this charge seriously. Although the compilers' criteria for what disasters they included are not stated, a consistency of reporting makes them a good starting point for reconstructing climate change. Long Wenbin 龍文涁 complained in his 1887 digest of the Ming statutes that "the two chapters of the Five Phases section of the Ming shi could not entirely record all categories of disaster," though he could not come up with much to supplement the record; Long Wenbin, Ming huiyao 明會要 (Beijing: Zhonghua shuju, 1956), juan 50-51.

${ }^{14}$ Song Lian, Yuan shi, 1051-1115.

${ }^{15}$ Zhang Tingyu 張廷玉, ed., Ming shi 明史 (Beijing: Zhonghua shuju, 1974), 28.426-30.512. The Ming shi introduces a few categories not found in the Yuan shi, notably a list of rat infestations between 1616 and 1644 (29.477).
} 
data primarily reflect temperature and precipitation anomalies, as well as their most common effect, famine. Most of these reports I felt confident to read in terms familiar to us; for example, treating reports of snow falling out of season as proxy data for abnormally cold weather. ${ }^{16}$

Regional gazetteers are the second source of data. Produced under official auspices, often under close editorial scrutiny from above, gazetteers chronicle the events, people, and institutions of an administratively defined area, from the county and sometimes below up to the prefecture and the province. Climate extremes are listed in sections entitled Xiangyi 祥異, “Auspicious Signs and Anomalies," or Zaixiang 災祥, “Disasters and Auspicious Signs." These lists consist of brief entries on local anomalies and disasters in chronological order. Like the historians at court, gazetteer editors could include the full range of Heavenly, Earthly, and Human anomalies, from dragon attacks and earthquakes to the birth of triplets and two-headed calves. Some simply list the events by date, while others offer editorial comments on how to interpret them. For example, the compiler of the disasters section of the 1630 gazetteer of Songjiang prefecture (the Shanghai region) interprets a huge snowstorm that blanketed Shanghai in three and a half meters of snow in January 1445 as a portent of a Japanese pirate attack later that year; he also links a rooster that uttered human speech in 1555 to another wave of Japanese piracy that year. ${ }^{17}$ Other compilers opted for greater metaphysical distance. The editor of a gazetteer for Hainan Island twelve years earlier vaguely opined that "when the mind is rectified and the physical self in harmony, Heaven and Earth will also be so," and left it at that. ${ }^{18}$

The disaster lists in gazetteers vary widely in terms of the information their compilers include. Some give only a handful of brief reports, others run on for a dozen pages. In their totality - gazetteers of the imperial era survive in the thousands - they provide historians with a rich trove of material for reconstructing climate. ${ }^{19}$

\section{METHOD}

This section will be as brief as the method is simple. The next three sections identify phases of cold and heat, of drought and excessive rainfall, and of severe famine, based on reports in the two dynastic histories and fourteen regional gazetteers, which were chosen at the rate of roughly one per Ming province. ${ }^{20}$ The data are displayed in

\footnotetext{
${ }^{16}$ Some meteorological events recorded in the histories I have excluded for lack of a sufficient understanding of how to treat them as climate proxies. Yi Tae-jin has been bolder, tabulating astronomical anomalies as meteor falls and deducing their meteorological effects; see his "Meteor Falls and Other Natural Phenomena between 1500-1750 as Recorded in the Annals of the Choson Dynasty," Celestial Mechanics and Dynamical Astronomy 69:1 (1997), 199-220.

${ }^{17}$ Songjiang fuzhi 松江府志 (1630), 47.19b-20a, 21b.

${ }^{18}$ Qiongzhou fuzhi 瓊州府志 (1618), 1-2.1a.

${ }^{19} \mathrm{~A}$ team of disaster historians under the direction of Jia Guirong 賈貴榮 and Pian Yuqian 駢宇騫 is photoreproducing the disasters sections of gazetteers to produce what they hope will be a complete archive of China's historical disasters. The first compilation, in ten volumes, covers North Zhili, Shanxi, and the northeast: Difangzhi zaiyi ziliao congkan 地方志災異資料叢刊 (Beijing: Guojia tushuguan chubanshe, 2010).

${ }^{20}$ I have drawn disaster data from eight provincial gazetteers: Anhui tongzhi 安徽通志 (1877), juan 347; Fujian tongzhi 福建通志 (1871), juan 271; Gansu xin tongzhi 甘肅新通志 (1909), juan 2; Hubei tongzhi
} 
Table 1, and arranged in visual form in Charts 1 to 3 . These charts mark the years that at least one of these sources identifies as severely cold, severely hot, excessively dry, excessively wet, or struck by severe famine. Tables 2 to 4 offer comparative perspectives based on these findings.

The section following these looks more closely at the impact these anomalies had at the local level on the basis of 553 reports of extreme grain prices drawn from hundreds of local gazetteers, based in turn on a survey of several thousand gazetteers. The findings of this section appear in Charts 4 to 6 .

The reason for presenting the data at a relatively gross level derives from my purpose, which is to produce a four-centuries-long profile of climate shifts and their environmental effect in the form of famines. This profiling has relied on three decisions-two simplications and one refusal-about how to compile and tabulate the data. The first simplification is to treat the data in the first three sections as though they applied to all of China, without distinguishing where the reports came from. Regional and local analysis is essential and remains to be done by those competent in statistical methods, but my method here is to make time in the longue durée, rather than space, the principal axis for organizing the data. The second simplification is that the data have been tagged by year, rather than by the season or month when the anomaly occurred. A more sensitive analysis will want to work at a finer temporal scale once this more basic research has been done, but in my view that basic research is still not yet in place. ${ }^{21}$

The refusal is that I have declined to follow the convention in climate research data analysis of resolving the data into five- or ten-year periods. This is generally done to smooth out short-term disturbances in the data in order to capture longer trends of climate change. Resolving the data at the annual level produces a "noisier" result, but it stays closer to how people experienced environmental stress. In the end, my interest is not in climate in general terms but in terms of how it is experenced, in terms of how it matters to the decisions that people make about how to organize their lives and respond to challenges. The difficulty is that we are left with 385 points along the Xaxis at each of which something either happens or does not. I address this difficulty in the penultimate section by proposing a way of grouping consecutive years when multiple negative factors coincide into multi-year, non-periodic periods of extreme stress, for which I coin the term "slough" ("slough" rhymes with "bough" in the UK, "through" in the US, and either in Canada). The literal meaning of a slough is a bog or marsh that becomes impossible to pass through. Although the word is not in the vocabulary

\footnotetext{
湖北通志 (1921), juan 75; Hunan tongzhi 湖南通志 (1885), juan 243; Shanxi tongzhi 山西通志 (1734), juan 30; Sichuan tongzhi 四川通志 (1816), juan 203; and Zhejiang tongzhi 浙江通志 (1735), juan 109. For provinces for which gazetteers were not readily available to me, I worked from six prefectural gazetteers: Jinan fuzhi 濟南府志 (1840), juan 20; Linqing zhouzhi 臨清州志 (1674), juan 3; Songjiang fuzhi 松江府志 (1630), juan 47; Suzhou fuzhi 蘇州府志 (1642); Yunzhong zhi 雲中志 (1652), the regional gazetteer of Datong, juan 12; and Zhending fuzhi 真定府志 (1762), juan 7.

${ }^{21}$ Zhang Chongwang 張崇旺 has recorded some of his disaster data for Jiangnan by year and month, some by year and season, and some by just year; Ming-Qing shiqi Jiangnan diqu de ziran zaihai yu shehui jingji 明清 時期江南地區的自然災害與社會經濟 (Fuzhou: Fujian renmin chubanshe, 2006). Dating by month is easier for moment-specific disasters such as earthquakes (217-20) than it is for weather anomalies. In any case, Zhang's principal axis of analysis is space (where disasters happen), not time (how disasters cause effects over many years).
} 
TABLE 1. Years of Major Temperature and Precipitation Anomalies and Famines, 1260-1644

\begin{tabular}{|c|c|c|c|c|c|c|}
\hline Reign eras & Year span & Warm & Cold & Dry & Wet & Famines \\
\hline \multirow[t]{3}{*}{ Zhongtong/Zhiyuan } & $1260-1294$ & & $1261-1265$ & $1262-1264$ & & \\
\hline & & & 1284 & 1281 & $1287-1289$ & $1281-1282$ \\
\hline & & & 1292 & 1286 & & $1288-1293$ \\
\hline Yuanzhen/Dade & $1295-1307$ & & & $1295-1301$ & 1302 & $1299-1300$ \\
\hline Zhida & $1308-1311$ & & & & 1308 & 1308 \\
\hline \multirow{2}{*}{ Huangqing/Yanyou } & $1312-1320$ & 1312 & $1313-1314$ & & $1311-1315$ & 1313 \\
\hline & & & $1317-1320$ & & $1318-1325$ & $1315-1316$ \\
\hline Zhizhi & $1321-1323$ & & 1323 & & & $1320-1324$ \\
\hline Taiding/Zhihe & $1324-1328$ & & 1325 & $1326-1330$ & & $1325-\overline{1330}$ \\
\hline Tianshun/Tianli/Zhishun & $1328-1333$ & & 1330-1332 & & & \\
\hline \multirow[t]{4}{*}{ Hongwu } & $1368-1398$ & & $1368-1381$ & $1370-1374$ & & 1369 \\
\hline & & & & & & 1373 \\
\hline & & & 1389 & & 1385 & 1386 \\
\hline & & & 1393 & 1393 & 1390 & 1391 \\
\hline Jianwen & 1399-1402 & & & & & \\
\hline \multirow[t]{2}{*}{ Yongle } & $1403-1424$ & & 1409 & & $1403-1416$ & $1403-1406$ \\
\hline & & & & & $1422-1425$ & $1415-1416$ \\
\hline Hongxi & 1425 & 1425 & & & & 1425 \\
\hline \multirow[t]{2}{*}{ Xuande } & $1426-1435$ & & & $1426-1427$ & & \\
\hline & & & & $1433-1434$ & & $\underline{1434-1435}$ \\
\hline Zhengtong & $1436-1449$ & 1438 & $1439-1440$ & $1437-1452$ & 1436 & $\overline{1438}-1441$ \\
\hline
\end{tabular}




\begin{tabular}{|c|c|c|c|c|c|c|}
\hline Jingtai & $1450-1456$ & & $1450-1455$ & & $1454-1456$ & $\begin{array}{l}1443-1445 \\
1450-1455\end{array}$ \\
\hline Tianshun & $1457-1464$ & $1457-1459$ & 1460 & $1459-1461$ & & $1456-\overline{1457}$ \\
\hline \multirow[t]{3}{*}{ Chenghua } & $1465-1487$ & 1466 & $1464-1465$ & $1466-1470$ & & $1465-1473$ \\
\hline & & $1470-1476$ & 1477 & & $1472-1475$ & $1477-1487$ \\
\hline & & 1484 & & $1482-1503$ & & \\
\hline \multirow[t]{2}{*}{ Hongzhi } & $1488-1505$ & 1497 & $1493-1496$ & & & 1494-1495 \\
\hline & & 1503 & & & & $1501-1505$ \\
\hline \multirow[t]{7}{*}{ Jiajing } & $1522-1566$ & & 1523 & & & 1524 \\
\hline & & & 1529 & & & 1529-1531 \\
\hline & & 1536 & & & $1536-1539$ & 1538 \\
\hline & & 1542 & 1543 & & & \\
\hline & & 1546 & 1545 & $1544-1546$ & & $\underline{1545}$ \\
\hline & & & & & $1551-1554$ & 1553 \\
\hline & & $1554-1568$ & & $1558-1562$ & & \\
\hline \multirow{4}{*}{ Wanli } & & 1602 & 1605 & & $1603-1607$ & \\
\hline & & & & 1609 & & \\
\hline & & & 1616 & $1614-1619$ & & $1615-1617$ \\
\hline & & & 1618 & & & \\
\hline Tianqi & $1621-1627$ & & 1620 & & $1626-1627$ & \\
\hline \multirow[t]{2}{*}{ Chongzhen } & $1628-1644$ & & $1629-1643$ & & & $1632-1638$ \\
\hline & & & & $1637-1643$ & & 1639-1641 \\
\hline
\end{tabular}

Note: Anomalous winter climate reports are counted in the year the winter ended, not began.

Underlining marks famines of peculiar severity. 
CHART 1. Warmer and Colder Years, 1260-1644



CHART 2. Drier and Wetter Years, 1260-1644

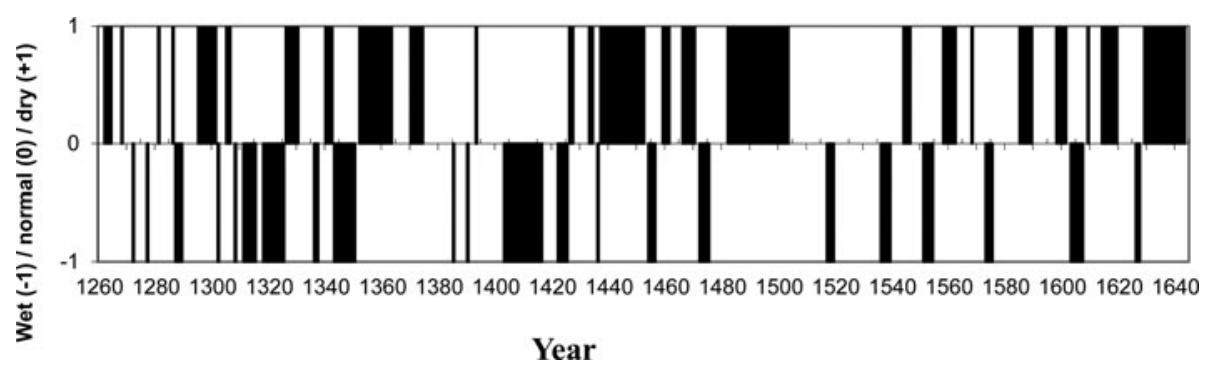

CHART 3. Famine Years, 1260-1644



of climate scientists, or of anyone for that matter, I needed a word to name something that I discovered needed naming. This section thus proposes a model to generate a chronology of climate change through the Yuan and Ming dynasties; this proposal is outline in Table 5.

4 COLD

What do the data reveal? Most basically, they reveal that the Yuan and Ming dynasties experienced temperatures below normal (see Chart 1). The period 1260-1644 began with one year of normal temperatures. The next year, 1261, the year after Khubilai Khan's elevation to the honor of Great Khan, the official history notes that the weather was colder than normal, and that it continued cold for five years in a row. Already in 1256 Khubilai 
had announced that he would abandon the Mongol capital of Qaraqorum in Mongolia for a more southerly location northeast of the Great Wall, which he named Shangdu 上都 (Xanadu), but in 1265, at the end of this first bout of cold, he ordered the new capital relocated another 300 kilomemeters further south to what is now Beiijing.

Colder weather is recorded again for the two years 1270-71, at the end of which Khubilai announced that his regime would take the dynastic title of Yuan, signalling his intention to base his rule in China and abandon Mongolia as his political center. Thereafter the Yuan stayed cold. Between 1260 and 1424, only one abnormally warm year is registered, 1312, as compared to sixty cold years. Radiocarbon dates taken from ice cores from glaciers on the Tibetan Plateau have been used to confirm the onset of the Little Ice Age to about $1300 .{ }^{22}$ The documentary data indicate, however, that temperatures had started falling forty years earlier, though it also shows that as of 1301 the colder weather was sustained. There were breaks in the 1330s and 1350s when temperatures returned to the normal range (1333-43, 1354-62). Thereafter colder weather continued unbroken from 1363 to 1381 .

The first phase of the Little Ice Age as reconstructed from Europe reached its nadir about 1370 . There then followed a century of moderate temperatures. Global cooling resumed about 1470, though only in the early 1480s did the cold became truly severe. ${ }^{23}$ The data for the first century of the Ming dynasty cleave to a similar pattern. The cold spell at the start of the dynasty ended in 1381, and with a few exceptions, colder temperatures did not return until 1450. At that point a six-year cold period takes over. In the summer of 1454, bamboo froze and canals across the Yangzi estuary were choked with ice. The following winter harbors froze over, boat traffic was suspended, and animals perished under a meter of snow. ${ }^{24}$ That period of intense cold (1450-56) was then followed by three years of warm weather (1457-59). The first seven years of the 1470s were abnormally warm (1470-76), followed by one year of extreme cold that froze canals on the Yangzi Delta to a depth of several feet, paralyzing transportation through the winter.

China then entered a phase during which temperature anomalies swung between extremes of cold and warm. ${ }^{25}$ Typical of this fluctuation was the reign of the Zhengde emperor (1506-21), during which China experienced six consecutive years of cold weather (1504-9), five of warm (1512-16), then two of cold (1518-19), a record that may have induced the widely shared perception that this was the bad reign of a fickle emperor. ${ }^{26}$ For the next quarter-century, temperature anomalies lasted no longer than a

\footnotetext{
${ }^{22}$ Jean Grove, "The Onset of the Little Ice Age," in History and Climate: Memories of the Future, edited by P.D. Jones et al. (New York: Kluwer, 2001), 160-62.

${ }^{23}$ Le Roy Ladurie, Histoire humaine et comparée du climat, 76-78, 140-55.

${ }^{24}$ Jiangdu xianzhi (1881), 2.13b.

${ }^{25}$ William Atwell has offered a similar, if slightly warmer, climate profile for the fifteenth century in his "Time, Money, and the Weather: Ming China and the "Great Depresion' of the Mid-Fifteenth Century," The Journal of Asian Studies 61:1 (February 2002), 84-85. Atwell's data are not specific to China but taken from other northern hemisphere locations; also, they are readings of summer anomalies rather than both summer and winter anomalies.

${ }^{26}$ Atwell, "Time, Money, and the Weather," 101-3, presents the early sixteenth century as more benign than my data suggest. For caustic late-Ming views of how bad the Zhengde era was, see Timothy Brook, The
} 
single year until 1554, when the people of the Ming experienced fifteen unbroken years of warm weather (1554-68), the longest spell of abnormally warm weather during the four centuries under study.

Thereafter the climate shifted. From 1569 until 1644, there would be only three years of warmer than normal temperatures. The cold returned in 1577; the following winter, lakes on the Yangzi Delta froze and winds blew the ice into mounds ten meters high. Over the sixty-eight years between 1577 and 1644, twenty-eight were abnormally cold. When the Jesuit missionary Matteo Ricci headed south on the Grand Canal after his first visit to Beijing in the winter of 1597-98, he discovered that "once winter sets in, all the rivers in northern China are frozen over so hard that navigation on them is impossible, and a wagon may pass over them." Ricci was puzzled, noting that "it is not quite clear as yet why the great rivers and lakes of north China should freeze thick in the winter." He speculated that it might have something to do with "their proximity to the snow-capped mountains of Tartary," as though the cold were a permanent regional condition that required explanation, not an anomaly - the doing of Earth rather than the working of Heaven, in Chinese cosmological terms. ${ }^{27}$ Had he not left Europe in 1577, just prior to the worldwide fall in northern-hemisphere temperatures, Ricci might have realized that the cold weather he experienced in Ming China did not need a local explanation: the cooling was global. Through the last half-century of the Ming, there was only a single year of abnormally warm weather (1602) as against twenty-three years of abnormally cold. Temperatures fell further in 1629 and remained low right through to the end of the dynasty. ${ }^{28}$ Other studies have suggested a depression of yearly temperatures during this period of roughly $-1{ }^{\circ} \mathrm{C}$, and of summer temperatures, $-2{ }^{\circ} \mathrm{C} .{ }^{29}$

A common cause of falling temperatures is volcanic spew. No major tectonic plates collide in China, hence almost no volcanic activity. But the eastern edge of the Eurasian plate abuts the Pacific plate just beyond Japan and the Philippines, placing China close to the constant seismic volatility along the so-called Ring of Fire. People living along China's southeast coast were certainly aware of constant seismic activity, though not of its causes or effects. The Fujian writer Xie Zhaozhe 謝肇淛, much interested in understanding the physical world, was curious as to why "Fujian and Guangdong are always moving." He doubted the common explanation that it was because "the water along the coast is so vast as to cause the earth to float," but could find no other explanation. ${ }^{30}$ Our interest is not in the earthquakes themselves, but for their link to colder temperatures due to the blocking of solar energy by sulphate aerosols.

Confusions of Pleasure: Commerce and Cuilture in Ming China (Berkeley: University of California Press, 1998), 144-47.

${ }^{27}$ Louis Gallagher, trans., China in the Sixteenth Century: The Journals of Matthew Ricci, 1583-1610 (New York: Random House, 1953), 14, 316.

${ }^{28}$ This late cold phase has been widely noted for some time; e.g., Zhang Jiacheng and Thomas Crowley, "Historical Climate Records in China and Reconstruction of Past Climates," Journal of Climate 2:8 (August 1989), 841. Zhang Jiacheng, The Reconstruction of Climate in China for Historical Times (Beijing: Science Press, 1988), 98, 107, proposes a larger pattern of cold and warm "ages" that does not tally with my findings; nor does his hypothesis of a regular, periodic pattern of drought phases find support in my data.

${ }^{29}$ As summarized in Ge et al., "Coherence of Climatic Reconstruction," 1014.

${ }^{30}$ Xie Zhaozhe 謝肇淛, Wu zazu 五雜沮 (Shanghai: Shanghai shudian, 2001), juan 4. 
TABLE 2. Major Seismic Events and Cold Years, 1260-1644

\begin{tabular}{|c|c|c|c|c|}
\hline Reign eras & Year span & Cold weather & Earthquakes & Sulfate spikes \\
\hline \multirow[t]{4}{*}{ Zhongtong/Zhiyuan } & $1260-1294$ & $1261-1265$ & & \\
\hline & & $1270-1271$ & & \\
\hline & & 1284 & & \\
\hline & & 1292 & $1290-1291$ & \\
\hline Yuanzhen/Dade & $1295-1307$ & $1301-1308$ & $\underline{1303-1308}$ & \\
\hline Zhida & $1308-1311$ & & & \\
\hline \multirow{2}{*}{ Huangqing/Yanyou } & $1312-1320$ & 1313-1314 & 1314 & \\
\hline & & $1317-1320$ & 1316 & \\
\hline Zhizhi & $1321-1323$ & 1323 & 1322 & \\
\hline Taiding/Zhihe & $1324-1328$ & 1325 & 1327 & \\
\hline Tianshun/Tianli/Zhishun & 1328-1333 & 1330-1332 & 1332 & \\
\hline \multirow[t]{5}{*}{ Yuantong/Zhiyuan/Zhizheng } & 1333-1368 & & 1336-1338 & \\
\hline & & $1344-1353$ & $1342-1343$ & \\
\hline & & & $1346-1347$ & \\
\hline & & & $1351-1352$ & \\
\hline & & $1363-1367$ & 1361 & \\
\hline \multirow[t]{4}{*}{ Hongwu } & 1368-1398 & $1368-1381$ & 1368 & \\
\hline & & & 1372 & \\
\hline & & 1389 & 1378 & \\
\hline & & 1393 & & \\
\hline Jianwen & 1399-1402 & & 1399 & \\
\hline \multirow[t]{2}{*}{ Yongle } & $1403-1424$ & 1409 & 1407 & 1409 \\
\hline & & & & $1417-1418$ \\
\hline Hongxi & 1425 & & 1425 & \\
\hline \multirow[t]{2}{*}{ Xuande } & $1426-1435$ & & 1427 & \\
\hline & & & 1433 & 1435 \\
\hline \multirow[t]{3}{*}{ Zhengtong } & 1436-1449 & $1439-1440$ & 1440 & \\
\hline & & & $1445-1446$ & 1445 \\
\hline & & & 1448 & \\
\hline Jingtai & $1450-1456$ & $1450-1455$ & & $1453-1454$ \\
\hline \multirow[t]{3}{*}{ Tianshun } & $1457-1464$ & & & $1456-1457$ \\
\hline & & 1460 & 1458 & 1459 \\
\hline & & 1464-1465 & & 1464 \\
\hline \multirow[t]{6}{*}{ Chenghua } & $1465-1487$ & & $1467-1469$ & 1467 \\
\hline & & & 1474 & $1471-1472$ \\
\hline & & 1477 & $1477-1478$ & $1477-1480$ \\
\hline & & $1481-1483$ & 1481 & \\
\hline & & & 1484-1485 & 1486 \\
\hline & & & $1487-1488$ & \\
\hline \multirow[t]{3}{*}{ Hongzhi } & $1488-1505$ & & & 1491 \\
\hline & & $1493-1496$ & $1494-1495$ & $1493-1495$ \\
\hline & & & $1498-1502$ & \\
\hline \multirow[t]{3}{*}{ Zhengde } & $1506-1521$ & 1504-1509 & $1505-1507$ & \\
\hline & & & 1509 & \\
\hline & & $1518-1519$ & $1511-1520$ & \\
\hline \multirow[t]{2}{*}{ Jiajing } & 1522-1566 & 1523 & $1522-1524$ & \\
\hline & & 1529 & $1526-1528$ & \\
\hline
\end{tabular}


TABLE 2. Continued

\begin{tabular}{|c|c|c|c|c|}
\hline Reign eras & Year span & Cold weather & Earthquakes & Sulfate spikes \\
\hline & & & 1535-1539 & \\
\hline & & 1543 & 1542 & \\
\hline & & 1545 & $1548-1549$ & \\
\hline & & & 1551 & \\
\hline & & & 1556 & \\
\hline & & & $\overline{1558}$ & \\
\hline & & & $1560-1562$ & \\
\hline \multirow[t]{2}{*}{ Longqing } & $1567-1572$ & & $1567-1569$ & \\
\hline & & & $1571-1574$ & \\
\hline \multirow[t]{7}{*}{ Wanli } & $1573-1620$ & $1577-1580$ & $1577-1591$ & \\
\hline & & 1587 & & \\
\hline & & $1595-1598$ & & \\
\hline & & 1605 & $1604-1612$ & \\
\hline & & 1616 & $1614-1616$ & \\
\hline & & 1618 & 1618 & \\
\hline & & 1620 & 1620 & \\
\hline \multirow{2}{*}{ Tianqi } & $1621-1627$ & & $1621-1624$ & \\
\hline & & & $1626-1627$ & \\
\hline \multirow[t]{2}{*}{ Chongzhen } & $1628-1644$ & $1629-1643$ & $1629-1636$ & \\
\hline & & & $1640-1644$ & \\
\hline
\end{tabular}

Underlining marks the years of most severe earthquakes.

Table 2 displays the data from the documentary record on major earthquakes during the Yuan and Ming, juxtaposed with years of extreme cold. ${ }^{31}$ It also shows sulfate spikes taken from glacial ice cores, indicating volcanic activity. ${ }^{32}$ The ice core data have a four-year margin of error, two in each direction. The correlation between earthquakes and cold weather is strong in every decade from the 1290 s to the 1360 s, especially the first decade of the fourteenth century. ${ }^{33}$ Earthquake activity subsided until the $1440 \mathrm{~s}$, then resumed on a fairly regular basis through the remaining two centuries of the Ming. The intense period of seismic activity from 1577 to 1591 is particularly suggestive in light of the climate-induced disasters of the late 1580s. The resumption of seismic activity in 1604, which included a quake that leveled the maritime commercial centers of Quanzhou and Zhangzhou on 29 December, was followed conspicuously by cold weather. ${ }^{34}$ Earthquakes thereafter appear to correlate with colder weather in the $1610 \mathrm{~s}$ and the late 1620 s to early 1640 s. To what degree earthquakes in China were tied to

\footnotetext{
${ }^{31}$ Song Lian, Yuan shi, 1082-84; Ming shi 30.493-505.

${ }^{32}$ Atwell, "Time, Money, and the Weather," 93.

${ }^{33}$ On earthquakes in this period, see Gu Gongxu et al., Catalogue of Chinese Earthquakes (1831 B.C.-1969 A.D.) (Beijing: Science Press), 19-21; Guojia dizhen ju diqiu wuli yanjiusuo 國家地震局地球物理研究所, ed., Zhongguo lishi dizhen tuji: yuangu zhi Yuan shiqi 中國歷史地震圖集: 遠古之元時期 (Beijing: Zhongguo ditu chubanshe, 1990), 151-56.

${ }^{34} \mathrm{Gu}$ Gongxu, Catalogue of Chinese Earthquakes, 44-52, 67-69. The Zhangzhou earthquake goes unmentioned in the Ming shi. The epicenter was far enough offshore (30 kilometers) that the destruction was limited.
} 
the climate forcing of volcanic emissions I leave to specialists, though the pattern of sulphate spikes suggests that this would be a fruitful avenue of inquiry. ${ }^{35}$

\section{DROUGHT}

If the documentary data reveal that the years of the Yuan and Ming dynasties were more often cold than warm, they also show them to have been more often dry than wet (see Chart 2). ${ }^{36}$ There was fluctuation between the two extremes, but droughts occurred more often than pluvials (periods of abundant precipitation) by a rate of three to two.

The Yuan dynasty was mostly a period of abnormally dry weather until the $1310 \mathrm{~s}$. Wet weather prevailed from 1311 to 1325 , and then again, though with some returns to normal, from 1336 through to 1350 , periods that also saw frequent floods. ${ }^{37}$ Thereafter China entered a period of either normal or abnormally dry weather until the wet years of the Yongle era in the early fifteenth century. ${ }^{38}$ Through the first half of the Ming dynasty (1368-1506), forty-six years were dry and twenty-eight wet. Except for brief wet interludes in 1454-56 and 1472-75, China continued dry into the next century. Not until 1504 did precipitation return to normal. There were pluvials in 1517-19 and 1536-39, but severe drought struck in 1544-46. From then on through the final century of the dynasty, China was more often abnormally dry than wet: thirty-one years of the one compared to fourteen of the other. The most severe droughts were in 1585-89 and 1614-19 - the fields were so parched in 1615 that the Ming shi reported that the landscape looked burnt. ${ }^{39}$ The most extreme dry phase was the last, from 1637 to 1643. This is the drought Zeng Yuwang has already described for us.

China's weather is shaped by both continental and maritime influences. Major deviations from normal rainfall in the tropical and temperate regions of the Pacific Ocean is usually theorized as the El Niño Southern Oscillation (ENSO). El Niño is the oceanic current on the west coast of South America, first observed by Peruvian fishermen who noticed that warm-water fish tended to supplant cold-water fish off the coast of Peru around Christmas, hence the nickname of El Niño, the Boy [Christ] Child. El Niño brings atmospheric effects of dense clouds, high humidity, and heavy rain. In most years the current alteration is brief, but roughly every four years, during a full Southern Oscillation, the distortion is great. Atmospheric conditions reduce the usual westward flow of warm water across the Pacific, causing a reverse advection. Meteorologically,

\footnotetext{
${ }^{35}$ One could propose connections between the eruption of Mount Asama, Japan, in 1331 and the cold phase of 1330-32; the eruption of Mount Iraya, Bataan, in 1464 and the cold phase of 1464-65 (supported by the sulphate spike that year); the eruptions of mounts Iwaki and Asama, Japan, in 1597-98 and the drought and famine of 1598-1601; and the eruption of Mount Iriga, Luzon, in 1628 just prior to the onset of the cool phase of 1629-43. This information is taken from Harris Lentz, The Volcano Registry: Names, Locations, Descriptions and History for over 1500 Sites (Jefferson, N.C.: McFarland, 1999).

${ }^{36}$ Annual precipitation maps compiled by the Central Hydrological Bureau present a year-by-year summary of precipitation based on reports taken from local gazetteers starting in 1470; Zhongyang qixiangju qixiang kexue yanjiuyuan 中國氣象局氣象科學研究院, Zhongguo jin wubai nian hanlao fenbu tuji 中國近五百年 旱澇分布圖集 (Beijing: Ditu chubanshe, 1981).

${ }^{37}$ Song Lian, Yuan shi XX.1051.52.

${ }^{38}$ This profile correlates significantly with Europe; Alexandre, Le Climat en Europe, 776-82.

${ }^{39}$ Zhang Tingyu, Ming shi, 30.485 .
} 
this reversal of warm water coincides with a switch in high pressure systems. As the high pressure cell over Easter Island (which drives the easterly winds that keep the waters off Peru cold) weakens, westerlies replace easterlies in the tropical belt, strengthening the low pressure cell over Indonesia and triggering anomalies in the western Pacific. According to geographer César Caviedes, when the Americas experience heavy rains and flooding during an El Niño year, in zones of Asia bordering the Pacific air pressures are high, ocean waters are colder than normal, and severe droughts replace the normal monsoons..$^{40}$

The El Niño effect cannot entirely explain the long stretches of dry weather in China. There are also longer-term continental influences, which can mask shorter-term ENSO effects. Nonetheless, droughts in China show some correlation with William Quinn's reconstruction of El Niño events since the 1540s. ${ }^{41}$ The data appear in Table 3. Certainly other factors are involved in shaping precipitation anomalies in eastern Asia, as research correlating drought years in China and low water years on the Nile has suggested. ${ }^{42}$ But ENSO may help to explain some dry periods during the Ming.

The ENSO pattern can entail a second stage, known as La Niña (the Girl Child). During a La Niña year, which tends to follow an El Niño year, conditions reverse: the eastern end of the tropical Pacific cools and the western end warms. As a result, zones that El Niño soaked in the Americas can experience drought during a La Niña, and drought zones in eastern Asia can receive an excess of rainfall. Whether the pluvial years indicated in Table 2 correlate with La Niñas requires further research. ${ }^{43}$

\section{FAMINE}

As noted, the history of disasters has been a popular topic with Chinese historians since the 1930s. Their abiding interest has been in the suffering that disasters imposed. Climate for them has been an exogenous factor, a force beyond human control but shaping of human experience, rather than an object of study. In this section, I turn now to evidence of disasters preserved in the dynastic histories and regional gazetteers as second-order proxies for climate change. These proxies are less dependable than weather reports for that purpose. While extreme weather can induce famines, floods, and epidemics, these events are mediated as well by human action. As economist Amartya Sen famously

\footnotetext{
${ }^{40}$ César Caviedes, El Niño in History: Storming through the Ages (Gainesville: University Press of Florida, 2001), 8-9.

${ }^{41}$ William Quinn, "A Study of Southern Oscillation-Related Climatic Activity for A.D. 622-1900 Incorporating Nile River Flood Data," El Niño: Historical and Paleoclimatic Aspects of the Southern Oscillation, ed. H. F. Diaz and V. Markgraf (Cambridge: Cambridge University Press, 1992), 126. This study is based on observations from regions other than China. Elsewhere, Quinn warns that El Niño is a regional ENSO manifestation, and that an El Niño event need not be matched elsewhere in the Pacific; William Quinn et al., "El Niño Occurrences over the Past Four and a Half Centuries," Journal of Geophysical Research 92 (1987), 14449.

${ }^{42}$ Zhang Jiacheng, The Reconstruction of Climate, 54.

${ }^{43}$ Michael Mann et al., "Global Signatures and Dynamical Origins," 1259, argue in favor of recognizing a stronger La Niña-like pattern in the Pacific during the Little Ice Age than previously recognized. Other research indicates that precipitation in north China may increase in La Niña years; see Wang Shao-wu and Wei Gao, "La Niña and its Impact on China's Climate," in La Niña and its Impacts: Facts and Speculation, ed. Michael Glantz (Tokyo: United Nations University Press, 2002), 188-89.
} 
Nine Sloughs 45

TABLE 3. ENSO Events Correlated with Major Droughts and Pluvials in China, 1544-1643

\begin{tabular}{|c|c|c|c|c|c|}
\hline Reign eras & Year span & & El Niño & Drought & Pluvial \\
\hline \multirow[t]{23}{*}{ Jiajing } & $1522-1566$ & 1544 & 1544 & 1544 & \\
\hline & & 1545 & & 1545 & \\
\hline & & 1546 & 1546 & 1546 & \\
\hline & & 1547 & 1547 & & \\
\hline & & 1548 & & & \\
\hline & & 1549 & & & \\
\hline & & 1550 & & & \\
\hline & & 1551 & & & 1551 \\
\hline & & 1552 & 1552 & & 1552 \\
\hline & & 1553 & & & 1553 \\
\hline & & 1554 & & & 1554 \\
\hline & & 1555 & & & \\
\hline & & 1556 & & & \\
\hline & & 1557 & & & \\
\hline & & 1558 & 1558 & 1558 & \\
\hline & & 1559 & 1559 & 1559 & \\
\hline & & 1560 & 1560 & 1560 & \\
\hline & & 1561 & 1561 & 1561 & \\
\hline & & 1562 & & 1562 & \\
\hline & & 1563 & & & \\
\hline & & 1564 & & & \\
\hline & & 1565 & 1565 & & \\
\hline & & 1566 & & & \\
\hline \multirow[t]{6}{*}{ Longqing } & $1567-1572$ & 1567 & 1567 & & \\
\hline & & 1568 & 1568 & 1568 & \\
\hline & & 1569 & & & \\
\hline & & 1570 & & & \\
\hline & & 1571 & & & \\
\hline & & 1572 & & & \\
\hline \multirow[t]{19}{*}{ Wanli } & $1573-1620$ & 1573 & & & 1573 \\
\hline & & 1574 & 1574 & & 1574 \\
\hline & & 1575 & & & 1575 \\
\hline & & 1576 & & & \\
\hline & & 1577 & & & \\
\hline & & 1578 & 1578 & & \\
\hline & & 1579 & 1589 & & \\
\hline & & 1580 & & & \\
\hline & & 1581 & 1581 & & \\
\hline & & 1582 & 1582 & & \\
\hline & & 1583 & & & \\
\hline & & 1584 & & & \\
\hline & & 1585 & 1585 & 1585 & \\
\hline & & 1586 & & 1586 & \\
\hline & & 1587 & & 1587 & \\
\hline & & 1588 & & 1588 & \\
\hline & & 1589 & 1589 & 1589 & \\
\hline & & 1590 & 1590 & & \\
\hline & & 1591 & 1591 & & \\
\hline
\end{tabular}


46 Timothy Brook

TABLE 3. Continued

\begin{tabular}{|c|c|c|c|c|c|}
\hline Reign eras & Year span & & El Niño & Drought & Pluvial \\
\hline & & 1592 & & & \\
\hline & & 1593 & & & \\
\hline & & 1594 & & & \\
\hline & & 1595 & & & \\
\hline & & 1596 & 1596 & & \\
\hline & & 1597 & & & \\
\hline & & 1598 & & 1598 & \\
\hline & & 1599 & & 1599 & \\
\hline & & 1600 & 1600 & 1600 & \\
\hline & & 1601 & & 1601 & \\
\hline & & 1602 & & & \\
\hline & & 1603 & & & 1603 \\
\hline & & 1604 & 1604 & & 1604 \\
\hline & & 1605 & & & 1605 \\
\hline & & 1606 & & & 1606 \\
\hline & & 1607 & 1607 & & 1607 \\
\hline & & 1608 & 1608 & & \\
\hline & & 1609 & & 1609 & \\
\hline & & 1610 & & & \\
\hline & & 1611 & & & \\
\hline & & 1612 & & & \\
\hline & & 1613 & & & \\
\hline & & 1614 & 1614 & 1614 & \\
\hline & & 1615 & & 1615 & \\
\hline & & 1616 & & 1616 & \\
\hline & & 1617 & & 1617 & \\
\hline & & 1618 & 1618 & 1618 & \\
\hline & & 1619 & 1619 & 1619 & \\
\hline & & 1620 & & & \\
\hline \multirow{7}{*}{ Tianqi } & $1621-1627$ & 1621 & 1621 & & \\
\hline & & 1622 & & & \\
\hline & & 1623 & & & \\
\hline & & 1624 & 1624 & & \\
\hline & & 1625 & & & \\
\hline & & 1626 & & & 1626 \\
\hline & & 1627 & & & 1627 \\
\hline \multirow[t]{13}{*}{ Chongzhen } & $1628-1644$ & 1628 & & & \\
\hline & & 1629 & & & \\
\hline & & 1630 & & & \\
\hline & & 1631 & & & \\
\hline & & 1632 & & & \\
\hline & & 1633 & & & \\
\hline & & 1634 & & & \\
\hline & & 1635 & 1635 & & \\
\hline & & 1636 & & & \\
\hline & & 1637 & & 1637 & \\
\hline & & 1638 & & 1638 & \\
\hline & & 1639 & & 1639 & \\
\hline & & 1640 & & 1640 & \\
\hline
\end{tabular}


TABLE 3. Continued

\begin{tabular}{|c|c|c|c|c|c|}
\hline Reign eras & Year span & & El Niño & Drought & Pluvial \\
\hline & & 1641 & & 1641 & \\
\hline & & 1642 & & 1642 & \\
\hline & & 1643 & & 1643 & \\
\hline
\end{tabular}

said of famines, "Starvation is the characteristic of some people not having enough food to eat. It is not the characteristic of there being not enough food to eat. While the latter can be the cause of the former, it is but one of many causes." ${ }^{44}$ Cold or drought can kill plants and cut off the harvest, but there are entirely human ways - war, siege, removal of labor, failure of storage, disruption of commercial circulation-to produce famine. China during the Yuan and Ming was generally a place where labor was abundant, grain stored, and grain markets efficient, and where major wars were limited to the dynastic transitions in the 1270s, the 1360s, and the 1640s. From this we can postulate that the correlation between famine and environmental stress should be high for most of that fourcentury period, particularly when famine extended beyond one season.

My interest in disasters is not only in their capacity to be second-order proxies, however. It is also in their potential for distinguishing the severity of climate anomalies. A cold year for which no famine is reported is likelier to have had a less depressed annual temperature than is a cold year for which famine is reported. The same relationship should be expected of famine and precipitation. Between the first phase of dearth (1268-72) in the era under Mongol rule and the last (1357-59), the people of the Yuan experienced a major famine every two years. Table 1 shows strong correlation between famine and drought through the first century of this period: in the late 1260s, the early $1280 \mathrm{~s}$, and the closing years of the thirteenth century, and through much of the 1320s to the 1350s. The worst famine decade for the Yuan was the 1320s, when the court went through five emperors, each one younger and less powerful than his predecessor. The people of the early Ming suffered occasional famines, but none was catastrophic until 1434. Two decade later came a half-decade of food shortages that peaked with the great famine of 1455 .

To situate China in relation to climate anomalies elsewhere, Table 4 juxtaposes the famine data from the thirteenth to fifteenth centuries with data for the same period in England. ${ }^{45}$ Scale would seem to rule out a comparison between a tiny kingdom and a large empire, but if we think of the earth as a single energy system in which a reduction in energy is at least as likely to be general as local, then it is not unreasonable to ask whether famine in one region might be echoed by famine in another. For the period 1260-1487, documentary evidence has yielded ninety-nine reports of major famines in

\footnotetext{
${ }^{44}$ Amartya Sen, Poverty and Famines: An Essay on Entitlement and Deprivation (Oxford: Clarendon Press, 1981), 1.

${ }^{45}$ Christopher Dyer, Standards of Living in the Late Middle Ages: Social Change in England, c. 1200-1500 (Cambridge: Cambridge University Press, 1989), 262-63, based on data in Thorold Rogers's multi-volume History of Agriculture and Prices in England.
} 
48 Timothy Brook

TABLE 4. Major Famine Years in China and England Compared, 1260-1487

\begin{tabular}{|c|c|c|c|}
\hline Reign eras & Year span & Famines in China & in England \\
\hline \multirow[t]{4}{*}{ Zhongtong/Zhiyuan } & $1260-1294$ & $1268-1272$ & $1274-1277$ \\
\hline & & $1281-1282$ & \\
\hline & & $1288-1293$ & $1293-1295$ \\
\hline & & $1299-1300$ & \\
\hline \multirow[t]{2}{*}{ Yuanzhen/Dade } & $1295-1307$ & $1302-1303$ & \\
\hline & & 1306 & \\
\hline \multirow{2}{*}{ Zhida } & 1308-1311 & 1308 & \\
\hline & & 1313 & \\
\hline Huangqing/Yanyou & $1312-1320$ & $1315-1316$ & $\underline{1315-1317}$ \\
\hline Zhizhi & $1321-1323$ & $1320-1324$ & $\overline{1321-1323}$ \\
\hline Taiding/Zhihe & $1324-1328$ & $1325-1330$ & \\
\hline Tianshun/Tianli/Zhishun & $1328-1333$ & & \\
\hline \multirow[t]{6}{*}{ Yuantong/Zhiyuan/Zhizheng } & 1333-1368 & 1333-1346 & 1331-1332 \\
\hline & & & $1346-1347$ \\
\hline & & $1352-1354$ & $1350-1353$ \\
\hline & & $1357-1359$ & \\
\hline & & & $1363-1364$ \\
\hline & & & $1367-1368$ \\
\hline \multirow[t]{4}{*}{ Hongwu } & 1368-1398 & 1369 & $1369-1371$ \\
\hline & & 1373 & $1374-1375$ \\
\hline & & 1386 & \\
\hline & & 1391 & 1390-1391 \\
\hline Jianwen & 1399-1402 & & \\
\hline \multirow[t]{3}{*}{ Yongle } & $1403-1424$ & $1403-1406$ & $1400-1402$ \\
\hline & & & $1408-1410$ \\
\hline & & $1415-1416$ & $1416-1419$ \\
\hline Hongxi & 1425 & 1425 & $1428-1430$ \\
\hline Xuande & $1426-1435$ & $1434-1435$ & \\
\hline \multirow[t]{2}{*}{ Zhengtong } & $1436-1449$ & $1438-1441$ & $1437-1440$ \\
\hline & & $1443-1445$ & \\
\hline Jingtai & $1450-1456$ & $1450-1455$ & \\
\hline Tianshun & $1457-1464$ & $1456-1457$ & $1460-1461$ \\
\hline \multirow[t]{2}{*}{ Chenghua } & $1465-1487$ & $1465-1473$ & \\
\hline & & $1477-1487$ & $1481-1484$ \\
\hline
\end{tabular}

Underlining marks famines of peculiar severity.

China and fifty-five in England. The two major European famines of this period are in 1315-17 (which in much of northern Europe continued to 1322) and 1437-40. ${ }^{46}$ For

\footnotetext{
${ }^{46}$ The first of these famines is documented in William Jordan, The Great Famine: Northern Europe in the Early Fourteenth Century (Princeton: Princeton University Press, 1996). Jordan notes that climate historians have identified 1310-20 as one of colder winters and wetter summers, without setting 1315 significantly apart from the years that preceded it. Against that record he pits documentary testimony that the winter of 1315 was unparalleled in its severity, and that 1316 was as bad or worse-neither of which the scientific
} 
these two famines, the correlation with dearth in China is strong. Famine struck the Yuan in 1315 in the wake of two cold years at precisely the same time that it struck northern Europe. Despite the onset of colder weather in 1317, the people of the Yuan experienced some relief in 1317-19, as did English people in 1318-20. But famine returned to China in 1320, reaching its shocking nadir in 1324. The great European famine of 1437-40 coincides loosely with a long stretch of dearth in China that began with the disastrous famine in 1434 and continued, with some interruptions, to 1445. Curiously, the sixyear Jingtai famine of 1450-55 finds no resonance in Europe. There is, however, considerable overlap between the two ends of the Eurasian continent in the 1480s. More can be done with this sort of cross-regional comparison.

Returning to Table 1 (see also Chart 3), we see that subsistence crises occurred intermittently but repeatedly through the second century of the Ming, crowned by three years of severe famine in 1544-46, the onset of which coincided with an El Niño year. According to a Zhejiang prefectural gazetteer, "the lakes dried up completely and became reddened earth." The price of grain skyrocketed. Anyone lucky enough to buy a liter of rice risked death as he carried it home. The government opened its granaries, but many of the famished starved to death on the road before they could get there. ${ }^{47}$

The greatest famine of the sixteenth century hit in the second decade of the Wanli era. ${ }^{48}$ It began in the north in 1586 , spread to South Zhili and Zhejiang the following year, and overwhelmed most of China in 1588. In Guangxi, provincial officials reported that "people are eating people and the corpses of the famished are scattered about unburied. In the cities and countryside are scenes that even a truly talented painter, were he here, would not be able to paint." 49 In 1589 dearth touched the interior agricultural provinces of Huguang and Jiangxi, though elsewhere the famine eased.

The most sustained and devastating period of famine in the Ming was the last. Cold descended in 1629 and famine was widespread by 1632. When drought returned in 1637 , it conspired with cold weather to produce the debilitating disasters that dominated the final years of the dynasty.The worst year was 1641, when famine reached Zeng Yuwang's area. The famine only really ended with the harvest of 1644, the year in which the Ming dynasty fell.

\section{GRAIN PRICES}

Local gazetteers furnish another set of famine data, although only for the period 1450-1644, that is both more local and more precise: reports of the high prices to which grain rose during the periods of greatest dearth. Roughly 3,000 local gazetteers from the late Ming to the Republic were surveyed to generate the 553 price records used in this essay. ${ }^{50}$ The price

evidence catches (16-18). The environmental context of the great famine gets the full attention of Le Roy Ladurie in his Histoire humaine et comparée du climat, 35-56.

${ }^{47}$ Shaoxing fuzhi 紹興府志 (1586), 13.32b.

${ }^{48}$ This famine is surveyed in Helen Dunstan's early path-breaking study, "The Late Ming Epidemics: A Preliminary Survey," Ch'ing-shih wen-t'i 3:3 (November 1975), 8-18.

${ }^{49}$ Mng shenzong shilu (Veritable records of the Wanli era), 197.3a, 11a.

${ }^{50}$ The data and method will be presented in greater detail in A Price History of the Ming Dynasty (Cambridge, Mass.: Harvard University Press, forthcoming). 
CHART 4. Famine Price Reports by Year, 1450-1644

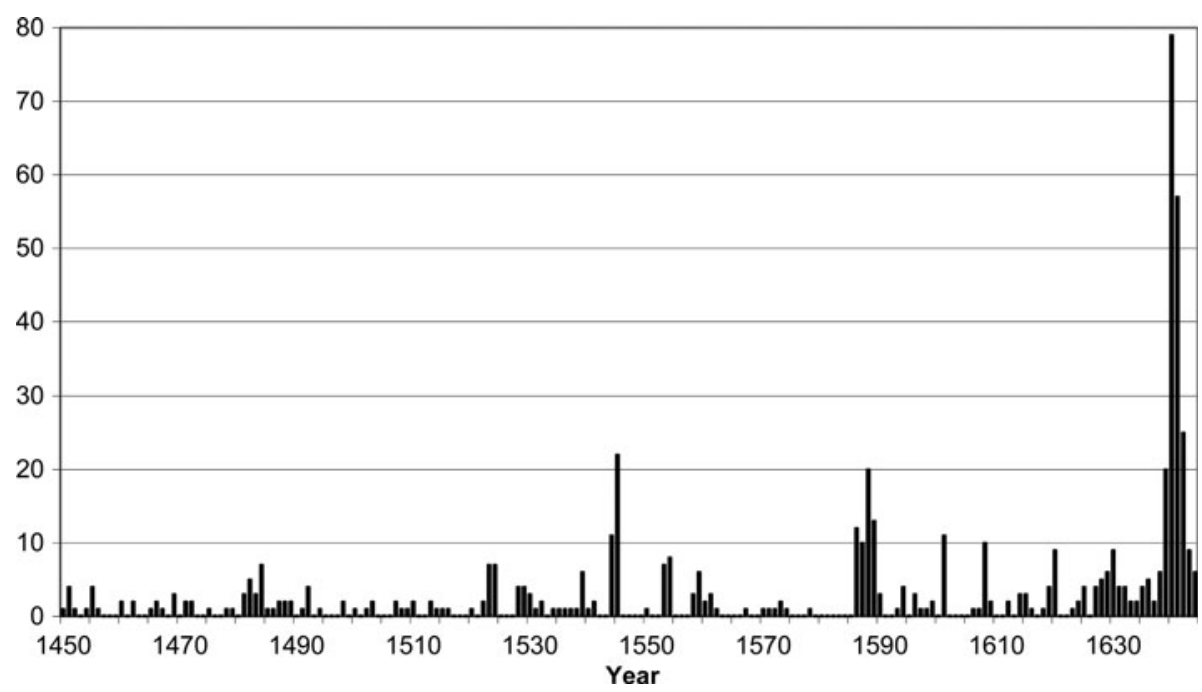

of grain was shaped by many factors in addition to the weather, but weather is fundamental in an agricultural regime, especially when an anomaly extends beyond a season. ${ }^{51}$ Grain prices during the dynasty's last half-century may have been inflated by the infusion of Japanese and American silver into the economy, but until there is clearer quantitative evidence, I proceed on the assumption that the greatest pressure on grain prices was the impact of poor weather on harvests.

The recording of disaster prices in local gazetteers is haphazard. There was no trigger for reporting one price over another, nor was there an expectation that a price should be reported. In fact, most compilers note simply that "the price of grain soared" without recording the price to which it soared. Enough compilers do list a price, though, that it has been possible to generate a series of hundreds of disaster grain prices. These price references were rhetorically charged to shock readers, but in doing so they tag the very worst famines. Since prices come with a numerical value, they can serve loosely to measure the comparative severity of a disaster. We have no way of checking whether the prices they give are accurate (prices across a single famine can vary) or knowing how they were calculated (did anyone actually pay these prices, or were they a fictive price that no one could afford?). But my sense is that a compiler would not include a price if he did not have some documentary evidence of its legitimacy.

\footnotetext{
${ }^{51}$ As Dyer has noted in his study of standards of living in England, "grain prices reflect a number of influences, including the supply of money, but the quality of the harvest provided the main cause of the sudden surge in prices"; see Standards of Living in the Later Middle Ages, 264. On the relationship between climate and grain prices in south China, see Robert Marks, "It Never Used to Snow': Climate Variability and Harvest Yields in Late-Imperial South China, 1650-1850," in Sediments of Time: Environment and Society in Chinese History, edited by Mark Elvin and Liu Ts'ui-jung (Cambridge: Cambridge University Press, 1998), 435-44.
} 
The data begin in 1450 because, with two or three exceptions, no gazetteer lists a famine price before that year. This was not because there were no famines, but because the grain market prior to 1450 was comparatively weakly developed and fewer people relied on markets to obtain grain than they would in the second half of the fifteenth century. That is to say, if there was no rice for sale in the local market, it couldn't have a price. Although these reports are individual and unsystematic, together they constitute the closest thing to a price data series for the Ming dynasty. They also provide an intriguing proxy for climate change.

Chart 4 displays the temporal distribution of the famine prices that I have collected for all grains. The first twelve reports belong to the years 1450-56. The next major cluster is in the mid-1540s: eleven in 1544, and twenty-two in 1545. There are fourteen reports in 1553-54 and nine in 1558-59; thereafter the reports dwindle. For the decade of 1575-85 I have found only one report of a famine price, in 1578. In 1586, this changes. Over 1586-89 there are fifty-three famine price reports. An even greater number is to be found in the late years of the dynasty. For 1639-43 there are 183 reports of famine prices: roughly a third of all price reports for the entire dynasty jammed into the five years before the dynasty fell.

Charts 5 and 6 present averages of the prices demanded for rice in particular (which sold slightly higher than other grains) during local famines: the first is based on reports of prices denominated in copper cash (wen 文), the second, in silver taels (liang 兩). The prices are per dou (10.5 liters or 2.5 US gallons). For the purpose of scale, the normal copper price of rice ranged from 25 to 30 cash. Chart 5, based on 136 reports, reveals that 100 copper cash-three to four times the normal priceemerged as the "standard" price to which rice rose in times of dearth during much of the Ming, though at times it went higher. The first time rice reached a price of 1,000 cash was in the great famine of 1587 , though the overall average of reported price in that famine is 550. The price of 1,000 cash appeared sporadically thereafter, and then was exceeded in the latter part of the Chongzhen era, when prices in some areas reached 3,500 cash (an average of 2,300 cash) in 1639 and 10,000 cash (an average of 3,167 cash) in 1640 .

Chart 6 displays 245 reports of famine rice prices recorded in silver taels. The normal silver price for rice ranged from 0.03 to under 0.04 tael per dou. A standard famine price in silver does not emerge as clearly from these data as it did for copper: it ranges from 0.1 to 0.15 tael (again, roughly three to four times the normal price). The earliest cluster of silver prices is from the Jingtai famine of 1450-56, though they are rare until the 1480s. There is a striking rise in 1513-14, after which the standard famine price moved up to about 0.2 tael in the 1540 s, then to 0.3 in 1545 , and again to that level in 1559-61. As with copper prices, the first big cluster of famine price reports in silver is for 1586-89, with 0.3 tael again emerging as the upper price to which rice could go. With two exceptions in 1595, that price does not reappear until $1614-18$.

In 1627 , and repeatedly from 1629, famine prices rise to new heights. 1639 is the first year in which the price is reported in exceptional cases as reaching and even exceeding 1 tael (there is a lone, exceptional price report of 1.7 taels in the far southwestern corner of today's Hunan in 1593). In many areas, the famine price of rice held within the range of 0.3-0.4 tael, but in other areas prices of 0.5 up to 2.4 taels were not uncommon. In 1643 





CHART 6. Average Famine Prices for Rice (Silver Taels), 1450-1644

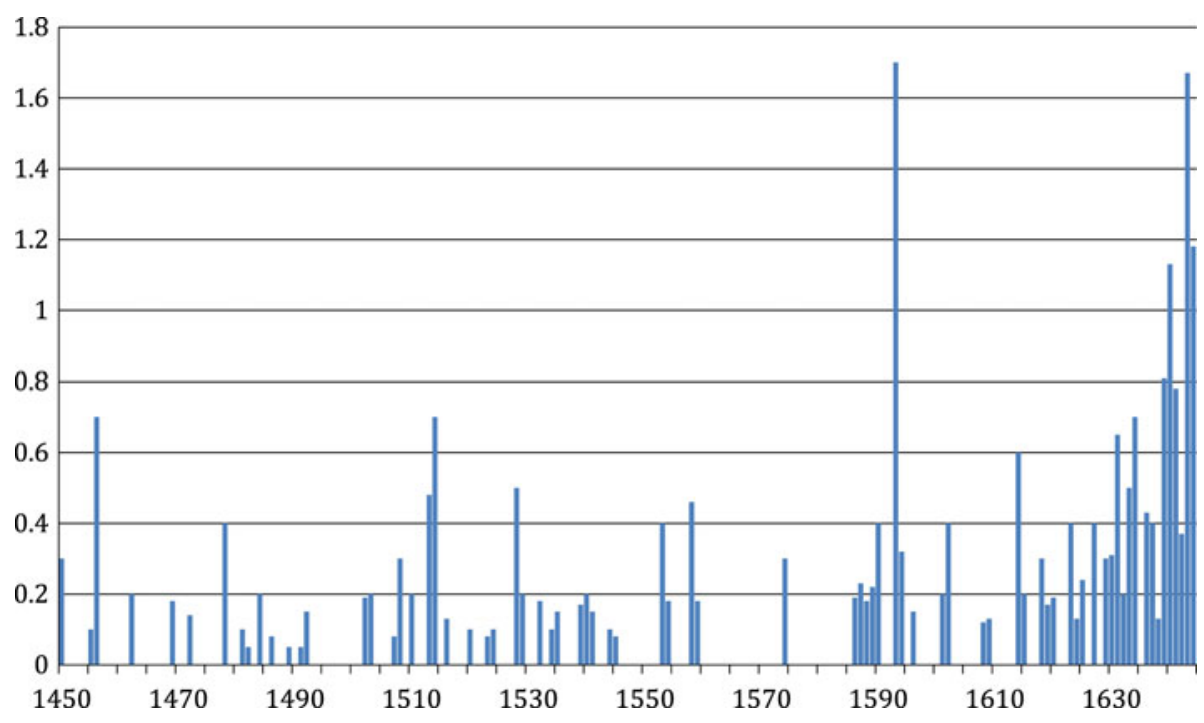

the average was 1.7 taels. These were unexperienced prices, and they mark this as possibly the period of greatest natural disaster in Chinese history.

\section{PERIODIZATION}

To conclude with the simple observation that the people of the Yuan and Ming experienced environmental stress in certain years and not in others does little more than state the obvious: that weather conducive to agricultural production deteriorated frequently but irregularly. To organize these findings into a more useful form, I have grouped the data to delineate nine multi-year periods, which I term "sloughs," a multi-year period when climate anomalies were powerful enough to compromise the survival of large numbers of people (see Table 5). ${ }^{52}$ To each slough I have attached the title of the reign era during which it occurred. This proved awkward for the reign of the Wanli emperor (1573-1620), for which period I have tagged the first slough as Wanli I and the second as Wanli II.

I have relied on three criteria to identify sloughs. Firstly, I looked for periods over several years when temperature and precipitation anomalies coincided, most often cold and drought, but sometimes cold and wet. Secondly, I looked for periods of severe famine that extended beyond a single year, when climate deviation was so great and so sustained as to threaten

\footnotetext{
${ }^{52}$ Further reflection has led me to revise two of the sloughs presented in The Troubled Empire. The main change has been to downgrade what I called the Yuanzhen and Zhengde Sloughs, and to designate more significant sloughs in the Zhiyuan and Yongle eras. My initial model sloughs included dragon sightings, which dynastic historians and gazetteer compilers reported as faithfully as they reported locusts; I have omitted them here on the grounds that their correlation with other anomalies, although richly suggestive for cultural history, is in fact rather weak.
} 
TABLE 5. Major Sloughs of the Yuan and Ming Dynasties

\begin{tabular}{|c|c|c|c|}
\hline Reign eras each emperor & Sloughs & Year span & Conditions \\
\hline $\begin{array}{l}\text { Zhongtong/Zhiyuan, 1260-1294 } \\
\text { Yuanzhen/Dade, 1295-1307 } \\
\text { Zhida, 1308-1311 } \\
\text { Huangqing/Yanyou, 1312-1320 } \\
\text { Zhizhi, 1321-1323 }\end{array}$ & Zhiyuan & $1268-1272$ & cold, dry \\
\hline $\begin{array}{l}\text { Taiding/Zhihe, 1324-1328 } \\
\text { Tianshun/Tianli/Zhishun, 1328-1333 }\end{array}$ & Taiding & 1324-1330 & dry \\
\hline $\begin{array}{l}\text { Yuantong/Zhiyuan/Zhizheng, 1333-1368 } \\
\text { Hongwu, 1368-1398 } \\
\text { Jianwen, 1399-1402 }\end{array}$ & Zhizheng & 1343-1346 & cold, wet \\
\hline $\begin{array}{l}\text { Yongle, 1403-1424 } \\
\text { Hongxi, 1425 } \\
\text { Xuande, 1426-1435 } \\
\text { Zhengtong, 1436-1449 }\end{array}$ & Yongle & $1403-1406$ & wet \\
\hline $\begin{array}{l}\text { Jingtai, } 1450-1456 \\
\text { Tianshun, 1457-1464 } \\
\text { Chenghua, 1465-1487 } \\
\text { Hongzhi, 1488-1505 } \\
\text { Zhengde, 1506-1521 }\end{array}$ & Jingtai & $1450-1455$ & cold \\
\hline $\begin{array}{l}\text { Jiajing, 1522-1566 } \\
\text { Longqing, 1567-1572 }\end{array}$ & Jiajing & $1544-1545$ & cold, dry \\
\hline Wanli, 1573-1620 & $\begin{array}{l}\text { Wanli I } \\
\text { Wanli II }\end{array}$ & $\begin{array}{l}1586-1588 \\
1615-1617\end{array}$ & $\begin{array}{l}\text { cold, dry } \\
\text { cold, dry }\end{array}$ \\
\hline $\begin{array}{l}\text { Tianqi, 1621-1627 } \\
\text { Chongzhen, 1628-1644 }\end{array}$ & Chongzhen & $1637-1643$ & \\
\hline
\end{tabular}

survival. Thirdly, where supplementary evidence was available, I consulted other indicators of environmental stress recorded in the dynastic histories, such as floods, epidemics, and locust infestations. One climate anomaly does not necessarily produce a slough; nor is one disastrous year sufficient to signal that a slough is underway. A slough happens when several factors combine over several years in a sustained, deadly combination, constituting something like a unified proxy of extreme climate anomaly.

Let me now re-narrate the climate disturbances presented in the previous sections in terms of these nine sloughs. The first in the Yuan dynasty is the Zhiyuan Slough (1268-72), replacing the Yuanzhen Slough (1295-97) in my earlier presentation. These were the cold, dry, famine-plagued years leading up to Khubilai's announcement of the founding of the Yuan dynasty at the end of 1271. The timing of this announcement may not have been unrelated to the slough, Khubilai seeking to persuade Heaven to alter its disposition and show its favor toward him. Distinguishing the negative environmental effects of climate through the decades of Khubilai's rule as a well-defined slough is not easy, however, as conditions were generally poor throughout the reign.

The next slough, by contrast, is unambiguous. The Taiding Slough (1324-30) struck as Khubilai's fifth successor came to the throne. The environmental pressures of drought and locust infestations led to severe famine, which fueled greater political instability through the mid- to late 1320s. Dating the end of the Taiding Slough to 1330 is somewhat arbitrary, as poor conditions continued on into the 1330 s. 
A further wave of famine and epidemics occurred in the context of excessive rainfall starting in 1343 followed by a fall in temperatures in 1344, creating the Zhizheng Slough (1343-46). This slough had an impact on the young rebel who would go on to the found the Ming dynasty, for Zhu Yuanzhang's biography in the dynastic history opens by declaring that "the year 1344 was a time of drought, locusts, great famine, and epidemics." 53 What else would an ambitious sixteen-year-old do but put himself on the road to founding a dynasty? Drought returned in force in the following decade. Although it induced three-year famines in 1352 and again in 1357, it is difficult to separate out any of these years as a distinctive slough. Further research on the Yuan dynasty may lead to a more complete list of sloughs during that dynasty.

By comparison with the Yuan, the Ming dynasty was remarkably free of disasters in its early years. The first downturn was the Yongle Slough (1403-6), a combination of famine, locusts, and floods that occurred in the context of excessive rainfall rather than drought.

Not until 1450, when a few gazetteers begin to record the prices to which grain rose during famines, were the people of Ming truly overwhelmed by a massive climate crisis, culminating in 1455 in one of the worst years of the century. This is the Jingtai Slough (1450-55), which coincided perfectly with the reign of the ill-starred Jingtai emperor, who was put on the throne to replace his half-brother, the Zhengtong emperor, taken hostage by a Mongol army in 1449.54 Zhengtong was returned to Beijing and lived under house arrest until his faction seized the throne in 1456, just as the slough was coming to an end. The Jingtai emperor, who died that spring, could not have chosen a worse half-decade to rule.

The weather remained generally poor through the rest of the fifteenth century. Although there were periods in the early 1480 s and the late 1510 s when difficult conditions intensified, the next major crisis was not until the drought of 1544, exacerbated the following year by a fall in temperatures. The intense dearth and epidemics of the Jiajing Slough (1544-45) is reflected by a surge in the number of reports of famine grain prices. ${ }^{55}$ Warmer weather returned in 1546. Despite drought in the late $1550 \mathrm{~s}$, the mid-sixteenth century was a benign environmental phase, which may have helped to lay the conditions for the prosperity enjoyed during the Wanli era.

Emperor Wanli was rewarded with enjoying the longest reign of any Ming ruler, fortyeight years, though that longevity, coinciding with the renewed onset of the Little Ice Age, dealt him not one slough but two. In a bold memorial to the emperor in 1597, midway between these two sloughs, the statecraft-minded official Lü Kun 呂坤 (1536-1618) dated the impoverishment of the people back to 1582, "since then no year has been without disaster." The date may well stand as marking the resurgence in

\footnotetext{
${ }^{53}$ Zhang Tingyu, Ming shi, 1.1 .

${ }^{54}$ Deteriorating conditions between 1434 and 1448 are noted by Twitchett and Grimm in The Cambridge History of China, vol. 7 (Cambridge: Cambridge University Press, 1998), 310-12, though their account stops short of Jingtai. Sulphur content in glaciers for the years 1453-54 indicates volcanic activity in this period; Atwell, "Time, Money, and the Weather," 93.

${ }^{55}$ Difficult environmental conditions in the 1540s are noted in passing in James Geiss' account of the Jiajing reign in The Cambridge History of China, vol. 7, 472-73.
} 
China of the Little Ice Age. ${ }^{56}$ Lü particularly singles out extreme cold as the main cause of suffering: "Your subjects' bones freeze for lack of warm clothing, their stomachs ache with hunger for lack of a next meal; their houses no longer keep a roof over their heads, the straw mats on which they bed down are in tatters." 57

The first period of sustained crisis in the era, Wanli Slough I (1586-89), started in a $\mathrm{Li}$ Niña year and grew into a massive climate disruption on a scale that dazed the regime. Conditions turned disastrous in the cold year of 1587, when famine, floods, locusts, and epidemics struck in unison. Europe experienced a severe famine crisis during 1586-87, suggesting that this slough coincided with a global climate crisis. ${ }^{58}$ The slough came to an end as temperatures warmed in 1589, though the drought was not relieved until the following year.

In 1614 the weather turned cold again and stayed cold for the next five years, creating the conditions for Wanli Slough II (1615-19). ${ }^{59}$ This slough began as a confusing patchwork of drought in some places and flooding in others. By the autumn of 1615, petitions for relief poured in from every direction. On November 25, two grand secretaries explained to the Wanli emperor that "although the situation differs in each place, all [reports] tell of localities gripped by disaster, the people in flight, brigands roaming at will, the corpses of the famished littering the roads. There is not one report that does not plead to receive the favor of your imperial grace." An illustrated memorial on the famine in Shandong, which reached the court in February 1616, estimated that over 900,000 people were on the brink of starvation, that local relief had run out, and that civil order had collapsed. ${ }^{60}$ The famine spread to the Yangzi valley later that year, Guangdong the next, and the northwest and southwest the year after that. To these were added massive sandstorms in 1618 and 1619, effects of the anthropogenic deforestation of the northwest. ${ }^{61}$ It is difficult to determine the end of this slough, for famine grain prices continued to be recorded through 1620.62

The Wanli emperor died that year just as the run of cold, dry years came to an end. Emperor Tianqi muddled his way through an eight-year reign that is remembered as

\footnotetext{
${ }^{56}$ Le Roy Ladurie locates the return of the Little Ice Age in Europe around 1573, though its full onset was delayed until 1586; Histoire humaine et comparée du climat, 221.

${ }^{57}$ These passages come from a memorial Lü submitted to the emperor in 1597, as preserved in Zhang Tingyu, Ming shi, 19/226/5938, quoted in Wang Ailing 王璦玲, Wan Ming Qing chu xiqu zhi shenmei gousi yu qi yishu chengxian 晚明清初戲曲之審美構思的藝術呈現 (Taipei: Zhongyang yanjiuyuan zhongwen wenzhe yanjiusuo, 2005), 504.

${ }^{58}$ Le Roy Ladurie, Histoire humaine et comparée du climat, 225-37.

${ }^{59}$ Robert Marks, writing on south China, regards 1614 as a turning point; China: Its Environment and History (Lanham: Rowman and Littlefeld, 2012), 188.

${ }^{60}$ Ming shenzong shilu, 538.2b, 539.9b, 540.7b, 542.2b. For reports of cannibalism from the 1615-16 famine in Shandong, see Xu Hong 徐泓, "Jieshao jize Wanli sishisan, si nian Shandong jihuang daozhi renxiangshi de shiliao" 介紹幾則萬曆四十三，四年山東饑荒導致人相食的史料, Mingdai yanjiu tongxun 6 (2003), 143-49.

${ }^{61}$ Zhang Tingyu, Ming shi, 30.512 .

${ }^{62}$ The rise of the Jurchens may be linked to Wanli Slough II. Nurhaci was still submitting tribute as late as 1615 , but drought and cold may have led him to change tactics, escalating his competition with the Ming, especially for the grain grown in Liaodong. In 1618, a cold, dry year, he launched an attack in eastern Liaodong and gained complete control of the region. The Ming counter-campaign the following spring collapsed at the battle of Sarhu on 14 April 1619.
} 
one of the worst-governed periods of the dynasty, though the weather returned to something close to normal. Tianqi's sixteen-year-old brother succeeded him as the Chongzhen emperor just as climate began to shift. The difficulties began during his first year on the throne, 1628, when Shaanxi succumbed to drought. Temperatures across the country plummeted the following year. Although conditions eased slightly through 1634-35, in 1637 the temperature dropped again, setting off the remarkable Chongzhen Slough (1637-43), the worst seven years of the dynasty. ${ }^{63}$ The numerous reports of extreme grain prices through these years are strong testimony - both in number and in priceof just how severe this crisis was. So too are the many memoirs that people such as Zeng Yuwang wrote to commeorate both the environmental stress of the Chongzhen Slough and the terrible political events that followed. Though the weather returned to something close to normal in 1644, rebels driven out of the northwest by famine captured Beijing and drove the last Ming emperor to suicide, and then the Manchus crossed the Great Wall and absorbed China into their Qing dynasty. ${ }^{64}$ These outcomes were not inevitable, yet none can be fully explained in the absence of climate change.

By analyzing environmental stress in the Yuan and Ming in terms of sloughs, I have offered a climate profile that varies from the findings of climate scientists. ${ }^{65}$ The variance is not huge: all studies, including this one, note trends consistent with the Mediaeval Warm Period and the Little Ice Age, and draw attention to the severe collapse of environmental security in the middle decades of the seventeenth century. The main difference stems from not resolving the data decadally and instead clustering anomalies into periods of variable length and separation. ${ }^{66}$ Even though this and previous reconstructions arise directly out of the documentary materials in which climate extremes were registered, the more flexible scaling used in this study enables the capture of the actual impact of climate. By registering patterns of anomaly not in aerosols or glacier mass but in human experience, we may come just a little closer to climate as a meaningful environment of history.

COLD AND DRY, BUT COLD

A general observation that Emmanuel Le Roy Ladurie makes in the massive survey of European climate history he completed a decade ago is that, "taken as a whole, it is really excessive precipitation which is by far the main danger for temperate climates

${ }^{63}$ The Chongzhen drought is explored in Jingyun Zheng, Lingbo Xiao, Xiuqi Fang, Zhixin Hao, Quansheng $\mathrm{Ge}$, and Beibei Li, "How Climate Change Impacted the Collapse of the Ming Dynasty," Climatic Change 127:2 (2014), 169-82. This study dates the onset of the drought to 1627 . While my data indicate that cold was the initial driving factor, drought became general only as of 1637. In support of the argument that climate anomalies precipitated the fall of the Ming, see Hai Cheng, Lawrence Edwards, and Gerald Haug, "Comment on 'On Linking Climate to Chinese Dynastic Change: Spatial and Temporal Variations of Monsoonal Rain," Chinese Science 55:32 (November 2010), 3734-37.

${ }^{64}$ For a broad-brush attempt to model the impact of climate anomalies on human disasters in this period, see Lingbo Xiao, Xiuqi Fang, Jingyun Zheng, and Wanyi Zhao, "Famine, Migration and War: Comparison of Climate Change Impacts and Social Responses in North China in the Late Ming and Late Qing Dynasties," The Holocene 25:6 (2015), 900-910.

${ }^{65}$ The following remarks are based on the summary of Chinese climate research in Ge et al., "Coherence of Climatic Reconstruction."

${ }^{66}$ The usefulness of Gao Wenxue 高文學, ed., Zhongguo ziran zaihai shi 中國自然災害史 (Beijing: Dizhen chubanshe, 1997), is similarly limited by reliance on ten-year resolution. 
such as ours in the middle of western Europe north of the Mediterranean." He regards wet and dry as the key register of climate variability, with wet as the more threatening pole. In fact, he suggests, "dryness is rather a good thing, at least so long as it is not accompanied randomly by heat or when it becomes excessive. As for cold, notably in winter, its effects are mitigated. It all depends on its modus operandi (with or without snow, for example) as to whether it is for good or for ill." 67

China taken as a whole presents a rather different picture. Of the climate anomalies we have examined, lower temperatures and drought posed the greatest threats to human survival during the four centuries of the Yuan and Ming. If I were to choose between these two factors, I would say that cooling was the stronger in terms of degrading the conditions society needed to reproduce itself. Cold - the climate signature of the Little Ice Age - is what played havoc. If any condition could be mitigated in the Chinese context, it was drought, thanks to an extensive irrigation infrastructure, except-as Le Roy Ladurie notes conversely of cold in Europe-when drought became excessive. Identifying global cooling rather than drought as the leading factor in the degradation of social and political order in the last fifteen years of the Ming is what the documentary proxies I have used in this essay suggest. Analyses based on other proxies may affirm this tentative conclusion or prove it wrong, but for now this formulation provides a way to begin integrating China into global climate history.

Curiously, at first glance, Zeng Yuwang does not mention the cold in his memoir of the relentless degradation of climate through the final years of the Ming dynasty. This may have been because he lived his entire life in the cold and did not think of cold weather as anything other than a constant. Yao Tinglin, who lived in the Shanghai countryside not far from Zeng Yuwang and also wrote a memoir recalling those terrible years, similarly focuses on the drought. By 1643 the dryness had become so extreme that the only way to get water was to go down to the long-dried-up riverbed and dig a deep hole in it. But cold does manage to make an appearance at an earlier point in his memoir in January 1636 when Yao was seven. His grandfather had just died, and on the morning of the 18th, the family gathered to accompany the coffin to the grave. Yao remembers the occasion not because he missed his grandfather, but because his uncle lost his temper at the coffin bearers, who showed up late. Their excuse was that it had been so cold that morning that this had delayed their arrival. ${ }^{68}$ The funeral would not have been record-worthy for the child, had it not been for his uncle's outburst, yet attached to that was his recollection that the temperature had been cold that morning. It is through passing references such as this one that we can access the experiences of the people of the Yuan and Ming and continue to reconstruct in greater detail and with greater accuracy climate change during these four centuries.

\footnotetext{
${ }^{67}$ Le Roy Ladurie, Histoire humaine et comparée du climat, 100.

${ }^{68}$ Yao Tinglin 姚廷遴, “Linian ji” 曆年紀 (A year-by-year record), reprinted in Qingdai riji huichao (see n. 5), 44.
} 